\title{
Marketing strategy planning at alfamart lodadi stores using the clustering, ahp, and ar-mba method
}

\author{
Fariza Halidatsani Azhra*, Najib Fadhlurrohman, Bagas Swardhana Putra, Faisal \\ Ibrahim
}

Department of Industrial Engineering, Universitas Islam Indonesia, Yogyakarta, Indonesia

farizazhra@gmail.com; 17522107@students.uii.ac.id; 17522268@students.uii.ac.id; faisal.ibrahim47@gmail.com

${ }^{*}$ Corresponding Author: farizazhra@gmail.com

ARTICLE INFO

\section{Keywords}

Analytical Hierarchy

Process;

Association Rule;

K-Means Clustering;

Market Basket Analysis;

Marketing Strategy

\section{Article history}

Received:

July 1, 2021

Revised:

July 26, 2021

Accepted:

August 30, 2021

Available online:

August 31, 2021

\section{ABSTRACT}

Nowadays, people are very facilitated by the existence of various shopping centers, including retail. Because many retailers are close to each other, Alfamart Lodadi must have a good marketing strategy. So far, the strategy used is sometimes inaccurate because it is not based on customer segmentation. Therefore, the purpose of this research is to help retail owners to make decisions regarding the right marketing strategy with three methods so that Alfamart Lodadi can compete and increase sales. The Analytical Hierarchy Process (AHP) is employed to find the priority variables of customer segmentation; meanwhile, the K-Means Clustering is used to group customers based on the similarity of predetermined characteristics. AR-MBA is used to find out the best rules, and products are rarely, sufficient, and frequently purchased. The results of this research, based on AHP, obtained five segmentation priority variables based on the largest eigenvector values. There are income, age, expenditure, distance, and shopping intensity with each eigenvector value of $0.13 ; 0.16 ; 0.12 ; 0.12 ; 0.17$. From clustering, there are three customer clusters with different strategies, including free shipping when shopping, product discounts for certain periods, and providing catalogs and discounts on each transaction and offer notifications. Then, this research also obtained three strategies based on AR-MBA. These include making a catalog by bringing frequently purchased products closer together, choosing a layout for shopping places by bringing frequently purchased products closer together, and making shopping coupons for rarely purchased products. With several strategic choices, companies can make decisions appropriately according to the desired criteria.

\section{Introduction}

Business is the main activity in supporting economic development. The small business sector is one of the most critical sectors in all countries, regardless of their economies and their stage of development (Alsaaty \& Makhlouf, 2020). Various businesses that are developing today make people feel very facilitated. The business is like a shopping center in markets, supermarkets, 
malls, and retail. Retail is a business activity that sells products or services that were previously given added value as an effort to fulfill the needs of individuals, families, groups, or end-users in retail quantities (Hikmawati \& Nuryakin, 2017). The retail sector is the most critical economic sector because it directly affects the consumer (Hameli, 2018). The retail industry sector has proliferated since the entry of modern retail, such as minimarkets in Indonesia (Wilandari \& Permadi, 2021).

Marketing is the main activity carried out by entrepreneurs to maintain the viability of their business, develop the company, and get the maximum profit (Zainurossalamia, 2020). Marketing is part of the company's management and is also one of the most critical factors in the company's success. Companies need to know the right and appropriate marketing strategy for the products to be sold in the market (Aisya \& Putri, 2018). With the right and proper marketing strategy, the product will be readily accepted by potential consumers to buy the products. In addition to the marketing strategy, the company needs to know the product's position while being sold. The current situation compares competitors' market share to market growth for similar products from other companies.

Applying the right marketing strategy enables the company to create, maintain, and develop consumer demand convincingly and sustainably (Lockett, 2018). Suppose sales turnover is experiencing a slow increase. In that case, an analysis should be done whether this is due to the ineffectiveness of the marketing strategy carried out or perhaps influenced by changing consumer tastes and behavior. With the rapid development of technology, enabling companies to produce these products and services is meaningless if it is not balanced by market them to consumers.

Alfamart is one of the retailers with an extensive reach, and one of them is located on $\mathrm{Jl}$. Kaliurang Km 14.5, Lodadi, Sleman, Yogyakarta. Because many retailers are close to each other, Alfamart Lodadi must have a good marketing strategy. So far, the method used is sometimes inaccurate because it is not based on customer segmentation. Therefore, the purpose of this research is to help retail owners to make decisions regarding the right marketing strategy with three methods so that Alfamart Lodadi can compete and increase sales. The Analytical Hierarchy Process is used to find customer priorities. In contrast, K-Means Clustering is used to group customers based on the similarity of predetermined characteristics. AR-MBA is used to find out the best rules and products that are rarely, sufficient, and frequently purchased.

\section{Literature Review}

Marketing is closely related to processes and society (Liu, 2017). Companies need to know the right marketing strategy, and potential consumers will readily accept the product. Among many methods for determining a company's marketing strategy, several popular methods have been used them. Analytical Hierarchy Process (AHP), Cluster Analysis, and Association Rules. However, in their use, each has its drawbacks. To remove the deficiencies, many studies have been proposed by experts.

The AHP used to create decisions with multiple criteria because this method provides for formulating the problem as a hierarchy and believes in a mix of quantitative and qualitative measures (Taherdoost, 2017). The research conducted by Sumanto and others used six criteria and six alternatives; an alternative ranking will be obtained as a reference for selecting a VSAT IT supplier for the Total EP Indonesia goods company. This method is considered more relevant in producing a decision and is more suitable for use in problems with complex quantitative data 
(Sumanto, Indriani, Marita, \& Christian, 2020). At the other research by Ray and Mangaraj, AHP can identify and rank six customer groups. It provides some possible strategies that can be considered to improve the relationship between a retailer and its customers. However, the researcher realizes that this research has room for improvement by using only one method to develop the desired strategy (Ray \& Mangaraj, 2016).

Clustering is used to group data based on similar characteristics. The research conducted by Nagari and Inayati uses the K-Means cluster to determine nutritional status. The study concluded that grouping nutritional status is possible by using K-Means with 4 clusters formed, which are 23 malnourished toddlers, 17 undernourished toddlers, seven nourished toddlers, and ten overnourished toddlers (Nagari \& Inayati, 2020). In other research states that customers are classified into four groups based on their buying behavior. In this research, various CRM strategies are brought forward to get a high level of customer satisfaction. The method's effectiveness is supported by improvements in several key performance indicators such as active customer growth, total purchase volume, and total consumption (Wu, et al., 2020).

Association rules are used to find association rules between data items. In the research conducted by Aprianti and others, association rules use to determine rules to identify related indicators of poverty and how the indicators inter-influence. Applying association rules with an apriori algorithm using minimum support of $30 \%$ and a minimum of $80 \%$ confidence generates 4614 rules of the relationship between indicators (Aprianti, et al., 2017). In the research conducted by Kurniawan and others, the test results show that the development from implementing market basket analysis through the rule association method using the a priori algorithm can run well. With a mean confidence value of $46.69 \%$ and a support value of $1.78 \%$, the number of rules generated is 30 rules (Kurniawan, et al., 2018).

The literature review above shows that great efforts have been made to improve the deficiencies in each of the previous studies. However, the limitations that are owned, such as the data obtained, often make research produce limited proposed strategies. Therefore, this study tries to provide choices for decision-makers in determining the marketing strategy that will be used not only from one segmentation criterion, namely AHP, which produces customer segmentation including income, age, location, and others. Clustering groups customers based on potential purchases, and AR-MBA sees customer behavior based on groups of goods that have been made. The hope is that with the choice of strategies offered, the company can make the right decisions.

\section{Research Methodology}

\subsection{Method of Collecting Data}

The data collection process is done by distributing questionnaires to 100 Alfamart Lodadi to find out the segmentation of customers who shop at that place. 100 data is considered to be representative of the population. In addition, literature studies from journals, books, proceedings in previous studies were also carried out.

\subsection{Research Location}

The research was conducted at Alfamart Lodadi which is located at Kaliurang Street km 14.5, Lodadi, Sleman, Yogyakarta. 


\subsection{Research Instruments}

In this research, the instruments used are as follows:

a. Questionnaires, used as a data collection tool used in the study.

b. SPSS \& Rapid Miner software, used as a statistical calculation tool in research.

\subsection{Data Processing}

In this research, the data processing methods used are as follows:

a. Decision Analysis

1. Analytical Hierarchy Process (AHP) is a functional hierarchy to help decision-makers make decisions on objective problems (Juliana, et al., 2017). AHP is used to determine the priority variables of customer segmentation.

b. Data Mining

1. Clustering groups similar objects in a cluster and different things in other clusters (Sano \& Nindito, 2016). Clustering is used to group customers who have similar characteristics based on predetermined variables.

2. Association Rule-Market Basket Analysis will find a pattern of data relations formed from a combination of an item set, so knowledge from a large dataset will appear (Ruswati, 2018). AR-MBA used to find out product items that are rarely, quite often, and often purchased by loyal customers and the best rules.

\subsection{Research Flow}

In this research, the research flow used is as shown in Figure 1. The first stage is collecting data using a questionnaire distributed to Alfamart Lodadi customers. The questions are related to customer data used as a customer segmentation variable such as income, age, location, expenses, public facilities, services, distance, and shopping intensity. After the data is collected, calculate the eigenvector to determine the priority of the variable using Ms. Excel. From the dominant variables, customers are grouped with K-Means Clustering. K-Means Clustering is an effective method to group customers based on the similarity of predetermined characteristics. The effectiveness of the process is supported by the results of improvements in several key performance indicators (Wu, et al., 2020). From these clusters, a suitable marketing strategy can be determined for each cluster. After knowing the characteristics of each cluster, then it is analyzed from what products are rarely, sufficient, and frequently purchased together with the Association Rules. Previous research proves that the test results show that the development from the implementation of market basket analysis through association rule can run well (Kurniawan, Umayah, Hammad, Nugroho, \& Hariadi, 2018). From this data, companies can make decisions according to the desired criteria, and the right strategy can be designed for Alfamart Lodadi.

\section{Results and Discussion}

\subsection{Result}

A. Variables in Customer Segmentation 
A market segment is a group of individuals, groups, or organizations who may share the same interests, traits, and characteristics (Camilleri, 2018). The market segmentation is divided into the following categories (Prasetyo, et al., 2017).

a. Demographic segmentation divides the market into groups based on gender, age, marital status, number of families, income, position, etc.

b. Psychographic segmentation, use of demographics in determining the behavior and tested specific segments of the population.

c. Buying decision

Purchase decision behavior refers to the final buying behavior of consumers, both individuals, and households who buy goods and services for personal consumption (Sjawal, Mananeke, \& Jorie, 2020).

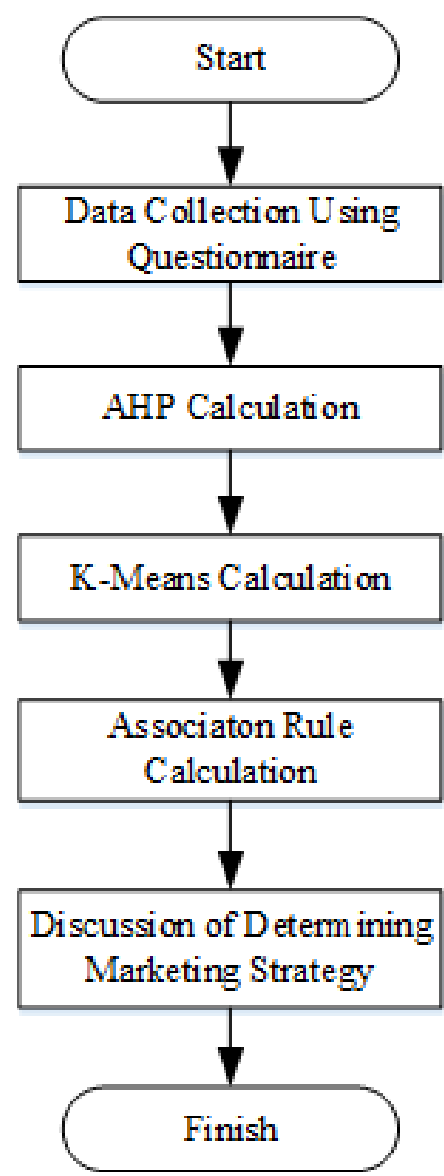

Figure 1. Research Model Flowchart

Researchers set several variables used to determine customer segmentation as follows: income, age, location, expenditure, public facilities, service, distance, shopping intensity B. Hierarchical Structure 
In AHP data processing, the first step is to structure the problem by building a hierarchy. Hierarchy created to breakdown customer segmentation variables. As presented in Figure 2, the variables used in determining customer segmentation include income, age, location, expenditure, public facilities, service, distance, shopping intensity.

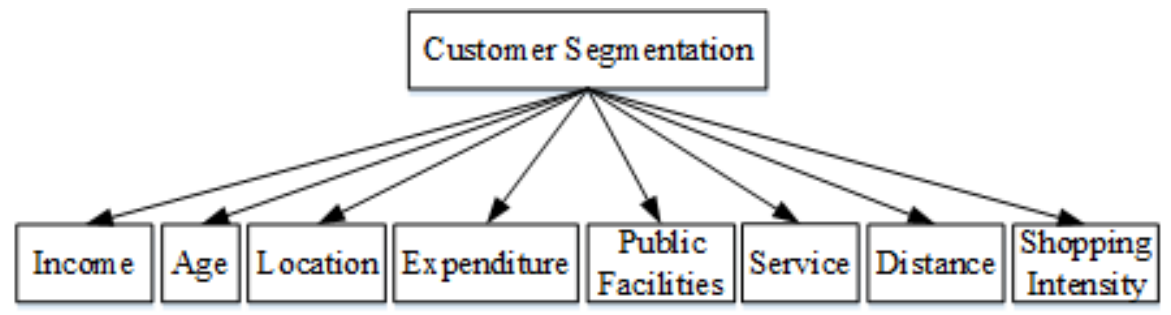

Figure 2. Customer Segmentation Hierarchy

Based on the picture of the hierarchical structure above, it can be seen that seven variables are considered to determine then the priority variables that will be used to determine the marketing strategy at Alfamart Lodadi.

\section{Pairwise Comparison Matrix}

After making a hierarchy, then collecting data by distributing questionnaires to Alfamart Lodadi customers, the data is converted into a pairwise comparison matrix (see Table 1). Each variable is compared to find out which variables have the most influence on sales. Then the value of each variable is added up vertically.

Table 1. Paired comparison based on questionnaires

\begin{tabular}{|l|c|c|c|c|c|c|c|c|}
\hline Criteria & Income & Age & $\begin{array}{c}\text { Locatio } \\
\mathbf{n}\end{array}$ & $\begin{array}{c}\text { Expendit } \\
\text { ure }\end{array}$ & $\begin{array}{c}\text { Public } \\
\text { Facilities }\end{array}$ & Service & Distance & $\begin{array}{c}\text { Shoppin } \\
\mathbf{g} \\
\text { Intensity }\end{array}$ \\
\hline Income & 1 & $1 / 5$ & $1 / 3$ & 2 & 3 & 1 & 5 & $1 / 2$ \\
\hline Age & 5 & 1 & $1 / 2$ & 5 & $1 / 3$ & 4 & $1 / 2$ & $1 / 5$ \\
\hline Location & 3 & 2 & 1 & $1 / 2$ & 1 & $1 / 3$ & 1 & $1 / 2$ \\
\hline $\begin{array}{l}\text { Expendit } \\
\text { ure }\end{array}$ & $1 / 2$ & $1 / 5$ & 2 & 1 & $1 / 2$ & $1 / 3$ & 2 & 5 \\
\hline $\begin{array}{l}\text { Public } \\
\text { Facilities }\end{array}$ & $1 / 3$ & 3 & 1 & 2 & 1 & $1 / 2$ & 1 & $1 / 4$ \\
\hline Service & 1 & $1 / 4$ & 3 & 3 & 2 & 1 & $1 / 2$ & $1 / 3$ \\
\hline Distance & $1 / 5$ & 2 & 1 & $1 / 2$ & 1 & 2 & 1 & 4 \\
\hline $\begin{array}{l}\text { Shoppin } \\
\text { g } \\
\text { Intensity }\end{array}$ & 2 & 5 & 2 & $1 / 5$ & 4 & 3 & $1 / 4$ & 1 \\
\hline Total & 13.033 & 13.7 & 10.83 & 14.2 & 12.83 & 12.167 & 11.25 & 11.783 \\
\hline
\end{tabular}

\section{Priority Determination}

The relative comparison values are then processed to determine the ranking of alternatives from all alternatives. AHP is a method for ranking decision alternatives and selecting the best one 
(George, et al., 2017). The weight or priority weight is calculated by dividing each cell value by the total of each column, as shown in Table 2.

Table 2. Priority weight

\begin{tabular}{|c|c|c|c|c|c|c|c|}
\hline Income & Age & Location & Expenditure & $\begin{array}{c}\text { Public } \\
\text { Facilities }\end{array}$ & Service & Distance & $\begin{array}{c}\text { Shopping } \\
\text { Intensity }\end{array}$ \\
\hline 0.0767 & 0.0147 & 0.0308 & 0.1408 & 0.2338 & 0.0822 & 0.4444 & 0.0424 \\
\hline 0.3836 & 0.0733 & 0.0462 & 0.3521 & 0.0259 & 0.3288 & 0.0444 & 0.0169 \\
\hline 0.2302 & 0.1465 & 0.0923 & 0.0352 & 0.0779 & 0.0274 & 0.0889 & 0.0424 \\
\hline 0.0384 & 0.0147 & 0.1846 & 0.0704 & 0.0389 & 0.0274 & 0.1778 & 0.4243 \\
\hline 0.0256 & 0.2198 & 0.0923 & 0.1408 & 0.0779 & 0.0411 & 0.0889 & 0.0212 \\
\hline 0.0767 & 0.0183 & 0.2769 & 0.2113 & 0.1558 & 0.0822 & 0.0444 & 0.0283 \\
\hline 0.0153 & 0.1465 & 0.0923 & 0.0352 & 0.0779 & 0.1644 & 0.0889 & 0.3395 \\
\hline 0.1535 & 0.3663 & 0.1846 & 0.0141 & 0.3117 & 0.2466 & 0.0222 & 0.0849 \\
\hline 1 & 1 & 1 & 1 & 1 & 1 & 1 & 1 \\
\hline
\end{tabular}

E. Calculation of Logical Consistency

Calculation of logical consistency is carried out by following these steps:

1. Multiply matrices with the corresponding priority.

2. Sum the multiplication results per row.

3. The result of the sum of each row is divided by the respective priority and sum of the results.

4. The result of $c$ divided by the number of elements will get $\lambda$ max.

5. Consistency Index

$$
\mathrm{Cl}=(\lambda \max -\mathrm{n}) /(\mathrm{n}-1)(1)
$$

Annotation (Saputra \& Nugraha, 2020):

$\mathrm{Cl}=$ Consistency Index

$\lambda$ max $=$ Principal eigenvector

$\mathrm{n}=$ number of criteria

6. Consistency Ratio (CR)

$$
\mathrm{CR}=\mathrm{Cl} / \mathrm{IR}
$$

IR is a random index of consistency. If the value is more than $10 \%$, then the assessment of the data must be corrected. However, the calculation result is correct. The calculation result is valid if the consistency ratio is less or equal to 0.1 ; the calculation result is correct (Mesra \& Saputra, 2020).

These calculations can be seen in Table 3 .

F. K-Means Cluster

K-Means Cluster is used to divide customers into groups with the same criteria (Aria, 2019). Calculation of K-Means Cluster is done with the help of SPSS software. There are three clusters to be formed as shown in Table 4. From the K-Means Cluster calculation, if the Zscore is positive, 
the cluster contains variables above the average. If the Zscore is negative, the cluster comprises variables below the average.

Table 3. Logical Consistency

\begin{tabular}{|c|c|c|c|c|c|c|}
\hline 1 & 2 & 3 & $4=3 / 2$ & $\begin{array}{l}\text { 5=Sum } \\
\text { 4/Sum1 }\end{array}$ & $\begin{array}{c}6=(5-S u m \\
1) /(\text { sum } 1- \\
1)\end{array}$ & 7 \\
\hline $\begin{array}{l}\text { Total Weight } \\
\text { Matrix }\end{array}$ & $\begin{array}{l}\text { Eugen } \\
\text { Vector }\end{array}$ & $\begin{array}{c}\text { Matrix } \\
\text { Multiplication }\end{array}$ & $\begin{array}{l}\text { Eugen } \\
\text { Value }\end{array}$ & $\lambda \max$ & $\mathrm{Cl}$ & IR \\
\hline 1.066 & 0.133 & 1.503 & 11.286 & \multirow{9}{*}{12.548} & \multirow{9}{*}{0.65} & \multirow{9}{*}{1.41} \\
\hline 1.271 & 0.159 & 2.053 & 12.917 & & & \\
\hline 0.741 & 0.093 & 1.203 & 12.994 & & & \\
\hline 0.977 & 0.122 & 1.592 & 13.043 & & & \\
\hline 0.708 & 0.088 & 1.165 & 13.176 & & & \\
\hline 0.894 & 0.112 & 1.223 & 10.947 & & & \\
\hline 0.960 & 0.120 & 1.622 & 13.516 & & & \\
\hline 1.384 & 0.173 & 2.163 & 12.503 & & & \\
\hline 8 & 1 & 12.525 & 100.38 & & & \\
\hline
\end{tabular}

Table 4. Output Final Cluster Centers

\begin{tabular}{|l|r|r|r|}
\hline \multirow{2}{*}{ Zscore } & \multicolumn{3}{c|}{ Cluster } \\
\cline { 2 - 4 } & \multicolumn{1}{c|}{$\mathbf{1}$} & \multicolumn{1}{c|}{$\mathbf{2}$} & \multicolumn{1}{c|}{$\mathbf{3}$} \\
\hline Age & -0.384 & 1.252 & -1.246 \\
\hline Income & -0.314 & 0.662 & 7.68 \\
\hline Shopping Intensity & -0.166 & 0.548 & -0.705 \\
\hline Expenditure & -0.374 & 1.227 & -1.427 \\
\hline Distance & 0.105 & -0.3 & -0.69 \\
\hline
\end{tabular}

\section{G. Departmental Grouping}

Departmental grouping is applying Market Basket Analysis rules to group products into one group of the same type. The data collected is 100 customers who have shopped at Alfamart Lodadi. According to Table 5, there are 8 departement at Alfamart Lodadi.

Table 5. Department Grouping

\begin{tabular}{|l|l|}
\hline Department & \multicolumn{1}{c|}{ Item } \\
\hline Dept 1 & Kitchen spices (e.g., Bango soy sauce, bimoli cooking oil, shallots, etc.) \\
\hline Dept 2 & Snack (e.g., Goodtime, sari roti, Roma) \\
\hline Dept 3 & Cigarettes (e.g., Malboro, Sampoerna, Dunhill) \\
\hline Dept 4 & Mineral Water (e.g., aqua, khq, Amanah) \\
\hline Dept 5 & Soft Drink (e.g. Fanta, coca cola, etc.) \\
\hline
\end{tabular}




\begin{tabular}{|l|l|}
\hline Department & \multicolumn{1}{|c|}{ Item } \\
\hline Dept 6 & Personal care equipment (e.g., Biore soap, pepsodent toothpaste, etc.) \\
\hline Dept 7 & Fruits and Vegetables (e.g., apples, kale, spinach, etc.) \\
\hline Dept 8 & Medicines (e.g. hansaplast, panadol, paramex, etc.) \\
\hline
\end{tabular}

\section{H. Association Rule}

As presented in Figure 3, to process data with rapid miners, first, determine the support value and confidence value. Support (supporting value) is the percentage of the combination of these items in the database, and confidence (certainty value) is the strength of the relationship between objects in the associative rule. In this research, the support value of 0.4 and the confidence value of 0.5 were used. The following is the result of the calculation of the association rule.

\begin{tabular}{|l|l|l|l|l|l|l|l|l|l|}
\hline No. & Premises & Conclusi... & Support & Confidence & LaPlace & Gain & p-s & Lift & Convicti... \\
\hline 1 & Dept 4 & Dept 6 & 0.330 & 0.569 & 0.842 & -0.830 & 0.011 & 1.034 & 1.044 \\
\hline 2 & Dept 2 & Dept 6 & 0.410 & 0.594 & 0.834 & -0.970 & 0.030 & 1.080 & 1.109 \\
\hline 3 & Dept 6 & Dept 4 & 0.330 & 0.600 & 0.858 & -0.770 & 0.011 & 1.034 & 1.050 \\
\hline 4 & Dept 2 & Dept 4 & 0.430 & 0.623 & 0.846 & -0.950 & 0.030 & 1.074 & 1.115 \\
\hline 5 & Dept 4 & Dept 2 & 0.430 & 0.741 & 0.905 & -0.730 & 0.030 & 1.074 & 1.199 \\
\hline 6 & Dept 6 & Dept 2 & 0.410 & 0.745 & 0.910 & -0.690 & 0.030 & 1.080 & 1.218 \\
\hline
\end{tabular}

Figure 3. Output Association Rule from Rapid Miner

From the output, it is known that the goods most likely to be purchased are based on the support value and confidence value. If the probability is higher, it means the possibility is more significant. For example, if Dept. 4 is purchased, it has a 56,9\% probability (confidence value) to buy the Dept. 6 . This rule is quite significant because it represents $33 \%$ (support value) of all transactions. Lift ratio $>1$ indicates the benefits of this rule-the greater the lift ratio, the greater the strength of the association. The results of these rules are used to determine the best strategy for promotion.

\subsection{Discussion}

Based on the calculation of the Analytical Hierarchy Process (AHP), it can be seen that the priority of determining the variable is based on the most significant eigenvector value. Five priority variables of customer segmentation were obtained from the seven variables, namely income, age, expenditure, distance, and shopping intensity, with each eigenvector value of $0.13 ; 0.16 ; 0.12$; $0.12 ; 0.17$.

Based on the K-Means Clustering, cluster 1 consists of consumers with dominant distance characteristics above the total average and other characteristics below the total average. Cluster1 includes customers who have less potential and are given a delivery service when shopping.

Cluster 2 consists of consumers with dominant distance characteristics below the total average and other characteristics above the total average. Cluster-2 includes a group of potential marketing target customers and is given a marketing strategy in the form of product price discounts for a certain period and the provision of catalogs. 
Cluster 3 consists of consumers with dominant income characteristics above the total average and other characteristics below the total average. Cluster 3 includes the most potential target customer group and is given a marketing strategy in the form of price discounts for each transaction and offer notifications.

Meanwhile, based on the results of the AR-MBA output, the following rules were obtained.

1. Dept. 4 will be purchased together with Dept. 6, with a confidence level of $56.9 \%$ and supported by $33 \%$ of the overall data.

2. Dept. 2 will be purchased together with Dept. 6, with a confidence level of $59.4 \%$ and supported by $41 \%$ of the overall data.

3. Dept. 6 will be purchased together with Dept. 4 , with a confidence level of $60 \%$ and supported by $33 \%$ of the overall data.

4. Dept. 2 will be purchased together with Dept. 4, with a confidence level of $52.3 \%$ and supported by $43 \%$ of the overall data.

5. Dept. 4 will be purchased together with Dept. 2, with a confidence level of $74.1 \%$ and supported by $43 \%$ of the overall data.

6. Dept. 6 will be purchased together with Dept. 2, with a confidence level of $74.5 \%$ and supported by $41 \%$ of the overall data.

The knowledge gained based on the rules used is categorized by bringing products often used together, making shopping coupons, making rare products, and choosing a layout for shopping places based on products usually placed together or near where they are placed. In the proposed layout (see Figure 4), Departments 4, 2, and 6 are brought together because they are often purchased together.

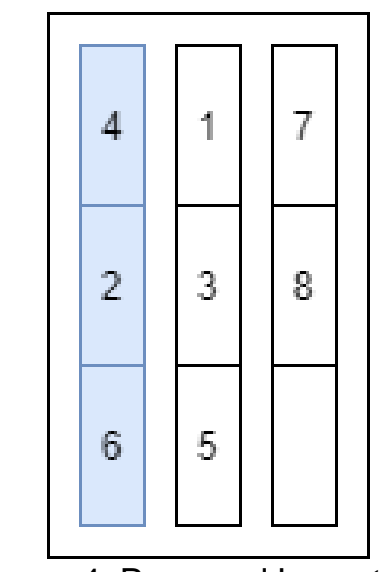

Figure 4. Proposed Layout

The proposed layout can be given by bringing departments 2, 4, and 6 closers by providing customer convenience in terms of purchasing habits. Making product layouts based on associations will influence consumers to buy other products when viewing other products arranged close together (Alfiqra \& Alfizi, 2018). This layout proposal refers to research which states that if there are apparel or accessories with certain brands that are not selling well, they can be placed in one storefront or shelf with the group. (Muzakir \& Adha, 2016). Another reference 
states that if the purpose of bundling is to increase sales, a rule that contains items that consumers often purchase is chosen, like rules that include necessities (Kuswayati \& Tjahyadi, 2017).

\section{Conclusion}

Based on the results of research conducted at Alfamart Lodadi, from the seven variables studied, including income, age, location, expenditure, public facilities, services, distance, and shopping intensity, five variables were selected that were appropriate as determinants of Alfamart Lodadi customer segmentation based on the highest eigenvector value. These variables include age, income, expenditure, shopping intensity, and distance. Based on the clustering method, 3 clusters were obtained with different strategies for each cluster. Cluster 1 is less potent and is given treatment in the form of delivery service/delivery when shopping, cluster 2 is quite potent and is given a marketing strategy in the form of product discounts for a certain period and cataloging, cluster 3 is the most potential and is given a marketing strategy in the form of discounts on each transaction and notifications offer. Based on the AR-MBA method, six rules were obtained. Three knowledge or strategy could be obtained, like cataloging by bringing frequently purchased products closer together, choosing a shopping place layout by bringing frequently purchased products closer together, and making shopping coupons for rarely purchased products. The three methods have their respective functions and advantages. AHP is used to find the priority variables of customer segmentation. K-Means Cluster is used to group customers based on the similarity of predetermined characteristics. In addition, AR-MBA is used to find out the best rules and products that are rarely sufficient and frequently purchased. With several strategic choices, companies can make decisions appropriately according to the desired criteria. However, this study has a lot of scope for its improvement. For example, future research can find ways to combine the marketing strategies that have been proposed from each method.

\section{References}

Aisya, A., \& Putri, S. (2018). Upaya Strategi Pemasaran Dalam Menciptakan Kepuasan Pelanggan (Studi Pengendalian Mutu di House Of Raminten Yogyakarta). Jurnal Ekonomi dan Bisnis, 1(1), 1-18.

Alfiqra, \& Alfizi, F. Y. (2018). Penerapan Market Basket Analysis Menggunakan Proses KDD Sebagai Strategi Penjualan Produk Swalayan (Studi Kasus : Swalayan X). IENACO (pp.509-516). Surakarta.

Alsaaty, F., \& Makhlouf, H. (2020). The Rise and Fall of Small Business Enterprises . Journal of Business and Management, 8(4), 1908-1916.

Aprianti, W., K. A., \& Rizani, M. R. (2017). Implementasi Association Rules dengan Algoritma Apriori pada Dataset Kemiskinan. Journal Mathematics and Its Application, 14(2), 145155. 
Aria, R. R. (2019). K-Means to Determine the e-commerce Sales Model in Indonesia. International Journal of Information System \& Technology, 3(2), 166-172.

Camilleri, M. A. (2018). Market Segmentation, Targeting and Positioning Chapter 4. In Travel Marketing, Tourism Economics and the Airline Product (pp. 69-83). Switzerland: Springer.

George, J., Singh, A., \& Diwan, V. (2017). Application of AHP for Finding out The Best Car Service Center in Bhopal: A Case Study. International Journal of Engineering and Technical Research, 7(5), 218-222.

Hameli, K. (2018). A Literature Review of Retailing Sector and Business Retailing Types. ILIRIA International Review, 8(1), 1-21.

Hikmawati, D., \& Nuryakin, C. (2017). Keberadaan Ritel Modern dan Dampaknya terhadap Pasar Tradisional di DKI Jakarta. Jurnal Ekonomi dan Pembangunan Indonesia, 17(2), 195-208.

Juliana, Jasmir, \& Jusia, P. A. (2017). Decision Support System for Supplier Selection using Analytical Hierarchy Process (AHP) Method. Scientific Journal of Informatics, 4(2), 158168.

Kurniawan, F., Umayah, B., Hammad, J., Nugroho, S. M., \& Hariadi, M. (2018). Market Basket Analysis to Identify Customer Behaviors by Way of Transaction Data. Knowledge Engineering and Data Science (KEDS), 1(1), 20-25.

Kuswayati, S., \& Tjahyadi, D. D. (2017). Market Basket Analysis Menggunakan Algoritma Apriori untuk Penetapan Strategi Bundling Penjualan Barang. Jurnal STT Bandung, 5(1).

Liu, R. (2017). A Reappraisal of Marketing Definition and Theory. Journal of Eastern Europe and Central Asian Research, 4(2), 1-7.

Lockett, A. (2018). Online Marketing Strategies for Increasing Sales Revenues of Small Retail Businesses. Minneapolis: Walden University.

Mesra, T., \& Saputra, J. (2020). Sistem Pengambilan Keputusan Memilih Kampus di Kota Dumai dengan Metode Analytical Hierarchy Process (AHP). Buletin Utama Teknik , 15(3), 207214.

Muzakir, A., \& Adha, L. (2016). Market Basket Analysis (MBA) Pada Situs Web E-Commerce Zakiyah Collection. Jurnal SIMETRIS, 7(2), 459-466.

Nagari, S. S., \& Inayati, L. (2020). Implementation of Clustering Using K-Means Method to Determine Nutritional Status. Jurnal Biometrika dan Kependudukan, 9(1), 62-68. 
Prasetyo, L., Moniharapon, S., \& Loindong, S. (2017). Pengaruh Faktor-Faktor Segmentasi Demografis dan Segmentasi Psikografis Terhadap Keputusan Pembelian pada Matahari Departement Store MTC Manado. Jurnal EMBA, 5(2), 1337-1347.

Ray, M., \& Mangaraj, B. (2016). AHP Based Data Mining for Customer Segmentation Based on Customer Lifetime Value. International Journal of Data Mining Techniques and Applications(IJDMTA), 5(1), 28-34.

Ruswati, A. I. (2018). Associative Analysis Data Mining Pattern Against Traffic Accidents Using Apriori Algorithm. Scientific Journal of Informatics, 5(2), 91-104.

Sano, A. V., \& Nindito, H. (2016). Application of K-Means Algorithm for Cluster Analysis on Poverty of Provinces in Indonesia. ComTech, 7(2), 141-150.

Saputra, M. I., \& Nugraha, N. (2020). Sistem Pendukung Keputusan dengan Metode Analytical Hierarchy Process (AHP). Jurnal Ilmiah Teknologi dan Rekayasa, 25(3), 199-212.

Sjawal, B. P., Mananeke, L., \& Jorie, R. J. (2020). Effect of Marketing Mix on Consumer Decisions to Choose Cafes (Case Study on BLEN.CO CAFÉ MANADO Consumers). EMBA, 8(3), 379-388.

Sumanto, Indriani, K., Marita, L. S., \& Christian, A. (2020). Supplier Selection Very Small Aperture Terminal using AHP-TOPSIS Framework. Journal of Intelligent Computing and Health Informatics , 1(2), 39-45.

Taherdoost, H. (2017). Decision Making Using the Analytic Hierarchy Process (AHP) : A Step by Step Approach. International Journal of Economics and Management Systems, 2(1), 244246.

Wilandari, A., \& Permadi, Y. A. (2021). Evaluasi Strategi Marketing Bisnis Ritel Skala Kecil Tradisional Kota Purwokerto Di Masa Pandemi Covid-19. Jurnal Administrasi Bisnis, 1(1), $1-8$.

Wu, J., Shi, L., Lin, W.-P., Tsai, S.-B., Li, Y., Yang, L., \& Xu, G. (2020). An Empirical Study on Customer Segmentation by Purchase Behaviors Using a RFM Model and K-Means Algorithm. Mathematical Problems in Engineering, 2020, 1-7.

Zainurossalamia, S. (2020). Manajemen Pemasaran Teori dan Strategi. Lombok Tengah: Forum Pemuda Aswaja. 
This page is intentionally left blank. 